Zeszyty Naukowe Szkoły Głównej Gospodarstwa Wiejskiego w Warszawie

Problemy Rolnictwa Światowego tom 18 (XXXIII), zeszyt 4, 2018: 13-22

DOI: 10.22630/PRS.2018.18.4.93

Pawel Kraciński ${ }^{1}$

Instytut Ekonomiki Rolnictwa i Gospodarki Żywnościowej - Państwowy Instytut

Badawczy w Warszawie

\title{
Konkurencyjność polskiego eksportu jabłek na rynki Wspólnoty Niepodległych Państw
}

\section{The Competitiveness of Apple Exports from Poland to the Markets of Commonwealth Independent States}

\begin{abstract}
Synopsis. Celem badań było określenie konkurencyjności eksportu jabłek z Polski na rynki Wspólnoty Niepodległych Państw. W artykule zidentyfikowano najważniejszych producentów oraz importerów netto z WNP. Przy wykorzystaniu mierników pozycji konkurencyjnej ex-post określono pozycję konkurencyjna eksportu z Polski na wybrane rynki WNP. W latach 2006-2016 Polska była największym dostawcą jabłek na Białoruś, do Kazachstanu oraz na Ukraine, a w latach 2006-2014 również do Rosji. Pozycja konkurencyjna eksportu jabłek z Polski obniżyła się w latach 2015-2016 na rynku białoruskim, a wzrosła na kazachskim i ukraińskim. W wyniku embarga na import jabłek z UE, wzrosła na rynku Federacji Rosyjskiej pozycja konkurencyjna dostaw z Serbii, Chin, Mołdawii oraz Białorusi.
\end{abstract}

Słowa kluczowe: eksport, import, jabłka, konkurencyjność

\begin{abstract}
The aim of the research was to determine the competitiveness of apple export from Poland to the CIS markets. In the paper the most important producers and net importers of apples from CIS were identified. Using the ex-post measures, the competitive position of Polish exports to selected CIS markets was determined. In 2006-2016, Poland was the largest supplier of apples to Belarus, Kazakhstan and Ukraine, and in 2006-2014 to Russia as well. The competitive position of apple exports from Poland decreased in the years 2014-2015 on the Belarusian market, and increased in the Kazakh and Ukrainian. As a result of the Russian embargo on the import of apples from the EU, the competitive position of supplies from Serbia, China, Moldova and Belarus increased in this market.
\end{abstract}

Key words: export, import, apples, competitiveness

JEL Classification: Q13, Q17

\section{Wprowadzenie}

Światowa produkcja jabłek w latach 2006-2016 rosła systematycznie osiagając $89 \mathrm{mln}$ ton $\mathrm{w}$ roku 2016. Przeciętnie globalne zbiory zwiększały się w tym czasie o 2,6 mln ton rocznie, a w Polsce średnio o 164 tys. ton rocznie. W latach 2015-2016 krajowa produkcja wyniosła $3,2 \mathrm{mln}$ ton. Zbiory jabłek w Polsce cechują się dużymi fluktuacjami w poszczególnych latach, na co wpływa pogoda, a zwłaszcza wiosenne przymrozki (Kraciński, 2018a).

Wolumen światowego eksportu jabłek w latach 2015-2016 osiagnął 8,8 mln ton, z czego z Polski wyeksportowano $0,9 \mathrm{mln}$ ton, co stanowiło $10 \%$ globalnego handlu

${ }^{1}$ mgr, Zakład Ekonomiki Ogrodnictwa, IERiGŻ - PIB, ul. Świętokrzyska 20, 00-002 Warszawa, e-mail: pawel.kracinski@ierigz.waw.pl; https://orcid.org/0000-0003-2906-8618 


\section{P. Kraciński}

zagranicznego tymi owocami. Światowy eksport w latach 2006-2016 zwiększał się przeciętnie o 148 tys. ton rocznie, podczas gdy eksport z Polski rósł o 69 tys. ton rocznie. Dzięki tak dużemu przyrostowi udział kraju w światowym handlu zwiększył się w stosunku przeciętnego wolumenu $z$ lat 2006-2008 o 5 p.p.

Pojęcie konkurencyjność wywodzi się od zjawiska konkurencji między podmiotami gospodarczymi. W literaturze użyto go pierwszy raz w latach 70. XX wieku, gdy naukowcy z USA starali się określić poziom konkurencyjności gospodarek USA oraz Japonii w wyniku silnej rywalizacji pomiędzy przedsiębiorstwami z tych krajów (Wziątek-Kubiak 2003). Brak jest jednej przyjętej i ogólnie akceptowalnej definicji konkurencyjności. Wynika to m.in. z tego, że konkurencyjność bada się na sześciu poziomach od pojedynczego produktu czy konsumenta po ujęcie globalne (Gorynia, 2009). Budnikowski (2003) definiuje konkurencyjność jako zdolność kraju do produkcji i sprzedaży dóbr i usług na rynkach zagranicznych. Instytut Ekonomiki Rolnictwa i Gospodarki Żywnościowej PIB określa konkurencyjność jako zdolność lokowania się krajowych producentów żywności na rynkach zagranicznych oraz zdolność rozwijania eksportu.

Zjawisko konkurencyjności należy rozpatrywać szerzej jako system składający się z potencjału konkurencyjnego (zasobów), instrumentów konkurowania (np. cena, jakość itd.), przewag konkurencyjnych (zastosowanie instrumentów), oraz zajmowanej pozycji konkurencyjnej (Stankiewicz, 2000). Pozycja konkurencyjna to zdolność konkurowania w danym momencie czasowym (Bieńkowski, Sadza, 2000). Konkurencyjność można analizować w odniesieniu do rynku krajowego (konkurencyjność wewnętrzna) oraz zagranicznego (konkurencyjność zewnętrzna lub międzynarodowa). Konkurencyjność krajowa to pozycja badanego obiektu (np. branży, sektora) względem pozostałych (Woś, 2001). Konkurencyjność międzynarodowa to rywalizacja na rynkach zagranicznych, a więc odnosi się do handlu zagranicznego.

Konkurencyjność analizowana jest ex-post oraz ex-ante (Frohberg, 2000). Pomiaru pozycji konkurencyjnej ex-post dokonuje się przy wykorzystaniu wskaźników, wśród których można wydzielić trzy grupy: mierniki przewag komparatywnych, mierniki udziałów w rynku lub handlu międzynarodowym oraz mierniki konkurencyjności cenowo-kosztowej.

Konkurencyjność eksportu jabłek z Polski znajdowała się już w kręgu zainteresowań badaczy. Kraciński (2016) badał pozycję konkurencyjną największych światowych eksporterów tych owoców w latach 2006-2015, przy wykorzystaniu mierników pozycji konkurencyjnej ex-post (saldo wymiany, udział w światowym eksporcie, wskaźnik relatywnej orientacji eksportowej, wskaźnik ujawnionej przewagi komparatywnej). Wyniki wskazały na wzrost konkurencyjność eksportu jabłek z Polski na rynku światowym do wprowadzenia przez Rosję embarga na import m.in. owoców z Unii Europejskiej.

Konkurencyjność eksportu jabłek z Polski badała również Trajer i in. (2014), wykorzystując dziesięć wskaźników mierzących pozycję konkurencyjnej ex-post, Analizy obejmowały lata 2003-2013 i wykazały wzrost pozycji konkurencyjnej eksportu jabłek z Polski.

Kowalska (2016) analizowała konkurencyjność zewnętrzną owoców świeżych i przetworzonych w latach 2004-2014. Pozycję konkurencyjną eksportu z Polski określono wykorzystując: wskaźnik pokrycia importu eksportem, wskaźnik relacji eksportowoimportowych Lafaya oraz wskaźnik handlu wewnątrzgałęziowego Grubela-Lloyda. Autorka wykazała, że konkurencyjność eksportu owoców świeżych z Polski była niska.

Badacze koncentrowali się również na identyfikacji najważniejszych odbiorców jabłek eksportowanych z Polski. Wyniki uzyskane przez Bugałę (2014), Kracińskiego (2014, 
2015), Jąder (2016), Filipiaka (2016), Ambroziaka (2017) wykazały, że Wspólnoty Niepodległych Państw (WNP), głównie Rosja była największym importerem jabłek z Polski. Eksport do krajów Unii Europejskiej (UE) był mniejszy, głównie dlatego, że zbiory Wspólnoty przekraczały zapotrzebowanie wewnętrzne (Kraciński, 2018b).

\section{Cel i metodyka badań}

Celem badań było określenie pozycji konkurencyjnej eksportu jabłek z Polski na rynkach krajów Wspólnoty Niepodległych Państw oraz ocena perspektyw rozwoju eksportu w najbliższych latach. Wśród krajów WNP zidentyfikowano importerów netto jabłek i określono dynamikę ich przywozu. Pozycja konkurencyjna eksportu jabłek z Polski na rynki krajów WNP pozostające importerami netto, została zbadana przy wykorzystaniu mierników ex-post.

W artykule wykorzystano dane o światowej produkcji i handlu jabłkami z baz danych Organizacji Narodów Zjednoczonych ds. Wyżywienia i Rolnictwa (FAOSTAT, UN Comtrade), a wielkości eksportu z Polski Ministerstwa Finansów RP. Okres badawczy obejmował lata 2006-2016. Podzielono go na trzy trzyletnie okresy (lata 2006-2008, 20092011, 2012-2014) oraz jeden dwuletni 2015-2016. Taki podział wynikał $\mathrm{z}$ chęci zmniejszenia wpływu o wahań produkcji i eksportu w poszczególnych latach. Fluktuacje w produkcji i eksporcie wynikają z wpływu pogody. W Polsce największe znaczenie mają wiosenne przymrozki, które w niektórych latach przyczyniają się do znacznych spadków zbiorów a za nimi eksportu. Ostatni okres obejmuje pierwsze lata po wprowadzeniu rosyjskiego embarga. Okres był krótszy, ale wynikał z odmiennych warunków w których przyszło funkcjonować eksporterom. Embargo zostało wprowadzone 1 sierpnia 2014 roku, jednak eksport jabłek z Polski odbywa się głownie od grudnia do sierpnia, dlatego większość eksportu z Polski w roku 2014 dotyczyła produkcji z roku 2013. W celu określenia tendencji, w opracowaniu porównano średnie wartości z lat 2006-2008 i 20152016. W bazie danych brak było danych handlowych dla Tadżykistanu, Turkmenistanu oraz Uzbekistanu, dlatego w odniesieniu do wielkości eksportu i importu podane wartości dotyczą pozostałych 8 krajów.

Pomiar pozycji konkurencyjnej jabłek eksportowanych z Polski na rynki krajów WNP dokonano przy użyciu:

1. Udziału w wolumenie eksportu do poszczególnych krajów WNP (UE)

$$
U E=\frac{E_{i c}}{E_{i w}} \times 100 \%
$$

$\mathrm{E}_{\mathrm{ic}}-$ eksport produktu $i$ z kraju $c$ na wybrany rynek;

$\mathrm{E}_{\mathrm{iw}}$ - światowy eksport produktu $i$ na wybrany rynek.

Udział eksportu produktu $i$ z kraju $c$ w światowym eksporcie na dany rynek $w$ jest jednym z najprostszych wskaźników mierzących pozycję konkurencyjną. Wzrost udziału w eksporcie na dany rynek $w$ interpretowany jest jako poprawa pozycji konkurencyjnej (Zawiślińska, 2003). Udział w eksporcie jest często stosowany w badaniach konkurencyjności zewnętrznej produktów. W przypadku analizowania jednego produktu można posłużyć się udziałem w wolumenie lub wartości eksportu. W artykule zastosowano udział w wolumenie eksportu. 
2. Wskaźnik ujawnionej przewagi komparatywnej (Revealed Comparative Advantage Index - RCA):

$$
R C A=\frac{E_{i c}}{E_{j c}}: \frac{E_{i w}}{E_{j w}}
$$

$\mathrm{E}_{\mathrm{jc}}-$ eksport grupy produktów $j \mathrm{z}$ kraju $c$;

$\mathrm{E}_{\mathrm{jw}}$ - światowy eksport grupy produktów $j$ na wybrany rynek

Miernik określa przewagę komparatywną eksportu z państwa $c$. Za twórcę uznaje się Balassę (1965). Wartości powyżej 1 oznaczają że eksport produktu $i$ z kraju $c$ jest konkurencyjny. W literaturze funkcjonują modyfikacje wskaźnika, ale pierwsza wersja jest nadal często stosowana. Zakres wartości przyjmowanych przez RCA pozwala wydzielić kraje pod względem siły przewagi komparatywnej w eksporcie produktu $i$ (Hinloopen i Marrewijk, 2001):

$0<$ RCA $\leq 1$ brak przewagi komparatywnej;

$1<$ RCA $\leq 2$ słaba przewaga komparatywna;

$2<\mathrm{RCA} \leq 4$ średnia przewaga komparatywna;

$4<$ RCA silna przewaga komparatywna.

Stosowanie RCA jest krytykowane ze względu m.in. z brak unormowania wartości (Salamaga, 2013). W badaniach grupę odniesienia do produktu $i$ (jabłka) (kod TARIC 080810) stanowiły owoce świeże wraz orzechami (kody od 0801 do 0810 ).

\section{Produkcja i handel zagraniczny jabłkami w krajach WNP}

W latach 2006-2016 rosły zbiory jabłek niemal we wszystkich krajach WNP. W latach 2015-2016 w stosunku do lat 2006-2008 produkcja jabłek w WNP wzrosła o 35\% do 5,7 mln ton (tab. 1). Przeciętny roczny wzrost zbiorów jabłek w krajach WNP osiagnął 184 tys. ton.

Tabela 1. Produkcja jabłek w wybranych krajach WNP w latach 2006-08, 2009-11, 2012-14 i 2015-16

Table 1. Production of apples in selected CIS countries in the years 2006-08, 2009-11, 2012-14 and 2015-16

\begin{tabular}{l|rrrrrrrrr}
\hline \multicolumn{1}{c}{ Lata } & \multicolumn{2}{c}{$2006-08$} & \multicolumn{2}{c}{$2009-11$} & \multicolumn{2}{c}{$2012-14$} & \multicolumn{2}{c}{$2015-16$} & \multicolumn{2}{c}{ Dynamika \% } \\
\multicolumn{1}{c}{ Kraje } & tys. ton & \multicolumn{1}{c}{$\%$} & tys. ton & \multicolumn{1}{c}{$\%$} & tys. ton & $\%$ & tys. ton & $\%$ & $\frac{2015-16}{2006-08}$ \\
\hline Lącznie & 4226 & 100,0 & 4188 & 100,0 & 5292 & 100,0 & 5716 & 100,0 & 135 \\
Azerbejdżan & 190 & 4,5 & 213 & 5,1 & 245 & 4,6 & 255 & 4,5 & 134 \\
Białoruśn & 377 & 8,9 & 383 & 9,1 & 445 & 8,4 & 432 & 7,6 & 115 \\
Kazachstan & 104 & 2,5 & 113 & 2,7 & 144 & 2,7 & 168 & 2,9 & 162 \\
Mołdawia & 225 & 5,3 & 229 & 5,5 & 320 & 6,0 & 360 & 6,3 & 160 \\
Rosja & 1697 & 40,1 & 1210 & 28,9 & 1533 & 29,0 & 1728 & 30,2 & 102 \\
Tadżykistan & 148 & 3,5 & 162 & 3,9 & 227 & 4,3 & 226 & 3,9 & 153 \\
Ukraina & 670 & 15,9 & 902 & 21,5 & 1141 & 21,6 & 1139 & 19,9 & 170 \\
Uzbekistan & 534 & 12,6 & 705 & 16,8 & 896 & 16,9 & 1090 & 19,1 & 204 \\
\hline
\end{tabular}

Źródło: opracowanie własne na podstawie danych UN Comtrade. 
Największymi producentami jabłek spośród krajów WNP były Rosja, Ukraina oraz Uzbekistan. Średnia wielkość zbiorów z tego największego producenta jabłek w WNP w latach 2015-2016 wynosiła 1,7 mln ton i była zbliżona do średniej produkcji z latach 2006-2008. W tym czasie wzrosły natomiast znacząco zbiory Uzbekistanu (104\%) oraz Ukrainy (70\%). W krajach tych produkcja jabłek w latach 2014-2016 wynosiła około 1,1 mln ton. Ważnym producentem jabłek w WNP jest Mołdawia. Zbiory w tym niewielkim kraju w latach 2015-2016 wyniosły 360 tys. ton ale wzrosły w stosunku do lat 2006-2018 o $60 \%$. Produkcja jabłek na Białorusi wzrosła w latach 2014-2015 w stosunku do lat 20062008 jedynie o $15 \%$ do przeciętnie 432 tys. ton tocznie. W badanym okresie obniżyły się jedynie zbiory jabłek w Armenii (o 13\%).

Tabela 2. Import netto jabłek w krajach WNP w latach 2006-08, 2009-11, 2012-14, 2015-16

Table 2. Net import of apples in the CIS countries in the years 2006-08, 2009-11, 2012-14, 2015-16

\begin{tabular}{|c|c|c|c|c|c|}
\hline Lata & 2006-08 & 2009-11 & $2012-14$ & 2015-16 & $\frac{2015-16}{2006-08}$ \\
\hline Kraje & tys. ton & tys. ton & tys. ton & tys. ton & $\%$ \\
\hline Łącznie & 217 & 324 & 404 & 523 & 242 \\
\hline Armenia & 0 & 1 & 0 & 0 & 72 \\
\hline Azerbejdżan & -78 & -46 & -48 & -13 & 17 \\
\hline Białoruś & 77 & 62 & 82 & 303 & 394 \\
\hline Kazachstan & 12 & 133 & 133 & 134 & 1090 \\
\hline Kirgistan & 40 & 0 & -18 & 1 & 4 \\
\hline Mołdawia & -77 & -168 & -152 & -113 & 146 \\
\hline Rosja & 932 & 1155 & 1226 & 769 & 82 \\
\hline Ukraina & 129 & 121 & 49 & 33 & 25 \\
\hline
\end{tabular}

Źródło: obliczenia własne na podstawie danych UN Comtrade.

Łączny import netto jabłek w krajach WNP w latach 2015-2016 wyniósł 523 tys. ton i był o $142 \%$ wyższy w porównaniu do wolumenu przywozu z lat 2006-2008 (tab. 2). Wśród krajów WNP jedynie Białoruś, Kazachstan, Rosja oraz Ukraina pozostawały w latach 2006-2016 importerami netto jabłek. Największym importerem netto jabłek była Rosja. Import jabłek do tego kraju rósł do lat 2012-2014, kiedy osiagnął poziom 1,2 mln ton, czyli $32 \%$ więcej w porównaniu do przeciętnego importu z lat 2006-2008. W latach 2014-2015 import Rosji obniżył się do 769 tys. ton, czyli 37\% względem lat 2012-2014. Tak duży spadek wynikał z wprowadzenia przez Rosję, w dniu 1 sierpnia 2014 roku zakazu importu m.in. owoców z terytorium UE.

Rosja pozostaje z Białorusią i Kazachstanem w Unii Celnej, dzięki czemu wymiana towarów między tymi krajami jest łatwiejsza. Białoruś i Kazachstan nie wprowadziły embarga na import z UE. Część importu realizowanego przez Białoruś oraz Kazachstan mogła służyć zwiększeniu eksportu do Rosji, na której rynku powstał duży niezagospodarowany popyt na jabłka. Import netto na Białorusi w latach 2015-2016 wyniósł 303 tys. ton i w stosunku do lat 2006-2008 zwiększył się blisko 4 - krotnie. Nadwyżka importu nad eksportem w Kazachstanie w stosunku do lat 2006-2008 wzrosła 10 - krotonie, ale zbliżony jej poziom (około 130 tys. ton) utrzymywał się już od lat 20092011. Wśród importerów netto z WNP najbardziej obniżył się import netto na Ukrainie, 
gdzie w latach 2015-2016 w relacji do lat 2006-2008 odnotowano jego 75\% spadek do zaledwie 33 tys. ton.

\section{Pozycja konkurencyjna polskiego eksportu jabłek na rynki krajów WNP}

Największym dostawcą jabłek na Białoruś w latach 2006-2016 była Polska (tab. 3). Udział naszego kraju $\mathrm{w}$ imporcie Białorusi obniżył się z maksymalnego poziomu $82 \%$ w latach 2009-2011 do 54\% w latach 2015-2016, co należy to intepretować jako spadek pozycji konkurencyjnej eksportu z Polski na Białoruś. Świadczy o tym również obniżka wskaźnika RCA z poziomu 5,7 w latach 2009-2011 do 2,8 w latach 2015-2016. Eksport z Polski w badanym okresie utracił silne przewagi komparatywne na rynku Białorusi. Mimo wzrostu wolumenu eksportu z Polski na Białoruś, jego konkurencyjność spadła. Wynikało to z rosyjskiego embarga, które wpłynęło negatywnie na wolumen sprzedaż jabłek z Polski. Owoce nie mogły być legalnie eksportowane do Rosji, dlatego na rynkach WNP większą rolę zaczęły odgrywać owoce importowane z innych krajów, np. z Półkuli Południowej. Większe znacznie na rynku białoruskim uzyskały owoce importowane z RPA, których udział w wolumenie importu tego kraju wzrósł z nieistotnego poziomu w okresach wcześniejszych do niespełna 6\% w latach 2015-2016. Wskaźnik RCA wskazywał jednak, że RPA nie miały przewag komparatywnych $\mathrm{w}$ eksporcie na rynek Białorusi. Większe znaczenie miał import jabłek z Mołdawii, który w latach 2015-2016 stanowił 9\% wolumenu przywozu tych owoców na Białorusi. Udział importu z Mołdawii obniżył się jednak w relacji do lat 2006-2009 o 19 p.p, co świadczyło o spadku pozycji konkurencyjnej eksportu z tego kraju. Eksport z Mołdawii na Białoruś w latach 2006-2008 i 2009-2011 posiadał przeciętne przewagi komparatywne, podczas gdy w ostatnich analizowanych okresach słabe.

Import jabłek w Kazachstanie realizowany był głównie z Polski, Białorusi oraz Chin. Udział eksportu z Polski w latach 2015-2016 stanowił 51\% wolumenu przywozu Kazachstanu wobec 5\% w latach 2006-2008. Udział ten zwiększał się systematycznie w analizowanych okresach. Eksport z Polski miał silne przewagi komparatywne na rynku Kazachstanu. Pozycja konkurencyjna eksportu z Polski mierzona udziałem w wolumenie przywozu wzrosła, a wskaźnik RCA wahał się od 13 do 25. W latach 2015-2016 wzrósł znacząco $\mathrm{w}$ porównaniu do okresów wcześniejszych (z 0 do 43\%), udział jabłek sprowadzanych z Białorusi w imporcie Kazachstanu, co można interpretować jako skutek zakłóceń w swobodnej wymianie handlowej między Rosją a Unią Europejską. Spadło natomiast znaczenie dostaw z Chin, których udział w latach 2015-2016 wyniósł zaledwie $11 \%$ wolumenu wobec $71 \%$ w latach 2006-2008. Eksport z Chin do Kazachstanu utracił w latach 2015-2016 przewagi komparatywne. Wynika to $z$ tendencji spadkowej eksportu jabłek z Chin, przy wzroście cen sprzedaży z tego kraju, co było skutkiem wzrostu konsumpcji wewnętrznej w Chinach (Nosecka i in., 2014).

Największym rynkiem zbytu jabłek wśród krajów WNP jest Rosja. W wyniku wprowadzenia przez Rosję embarga, struktura importu do tego kraju uległa zmianie. Do 2015 roku największym dostawcą jabłek na rynek rosyjski była Polska. Udział importu z Polski wrósł z 19\% wolumenu przywozu w latach 2006-2008 do 47\% w latach 2012-2014. Eksport z Polski miał najwyższe i wzrastające przewagi komparatywne. Owoce importowane z Polski wypierały jabłka innych dostawców z rynku rosyjskiego (m.in. z Chin czy Włoch). 
Tabela 3. Pozycja konkurencyjna największych dostawców jabłek na wybrane rynki krajów WNP w latach 200608, 2009-11, 2012-14, 2015-16

Table 3. Competitive position of main supplier of apples to the selected markets of CIS countries in the years 2006-09, 2009-11, 2012-14, 2015-16

\begin{tabular}{|c|c|c|c|c|c|c|c|c|}
\hline \multirow{3}{*}{$\begin{array}{l}\text { Lata } \\
\text { Kraje }\end{array}$} & \multicolumn{4}{|c|}{$\mathrm{RCA}$} & \multicolumn{4}{|c|}{ Udział w wolumenie eksportu } \\
\hline & 2006-08 & $2009-11$ & $2012-14$ & $2015-16$ & $2006-08$ & $2009-11$ & $2012-14$ & $2015-16$ \\
\hline & & & & & & & & \\
\hline & \multicolumn{8}{|c|}{ Białoruś } \\
\hline Polska & 4,2 & 5,7 & 3,5 & 2,8 & 61,6 & 82,2 & 75,7 & 53,9 \\
\hline Mołdawia & 3,1 & 2,3 & 1,4 & 1,3 & 28,2 & 9,7 & 9,7 & 9,2 \\
\hline \multirow[t]{2}{*}{ RPA } & 0,0 & 0,1 & 0,0 & 0,7 & 0,0 & 0,0 & 0,0 & 5,9 \\
\hline & \multicolumn{8}{|c|}{ Kazachstan } \\
\hline Białoruś & 0,0 & 0,0 & 13,6 & 5,1 & 0,0 & 0,0 & 8,0 & 43,0 \\
\hline Chiny & 11,2 & 6,8 & 5,7 & 2,5 & 70,5 & 66,3 & 24,3 & 10,7 \\
\hline \multirow[t]{2}{*}{ Polska } & 19,8 & 13,4 & 24,7 & 15,1 & 4,9 & 16,0 & 37,3 & 50,9 \\
\hline & \multicolumn{8}{|c|}{ Rosja } \\
\hline Białoruś & brak & brak & 12,0 & 7,0 & brak & brak & 7,3 & 8,6 \\
\hline Chiny & 10,2 & 7,6 & 5,3 & 4,1 & 21,0 & 13,5 & 8,8 & 14,8 \\
\hline Włochy & 6,2 & 6,5 & 7,7 & embargo & 5,6 & 5,1 & 3,1 & embargo \\
\hline Mołdawia & 11,5 & 15,9 & 11,8 & 7,7 & 4,1 & 13,6 & 9,7 & 12,3 \\
\hline Polska & 16,4 & 17,6 & 19,5 & embargo & 19,3 & 28,0 & 46,9 & embargo \\
\hline \multirow[t]{2}{*}{ Serbia } & 13,1 & 11,8 & 11,8 & 11,9 & 3,1 & 6,1 & 6,8 & 23,8 \\
\hline & \multicolumn{8}{|c|}{ Ukraina } \\
\hline Italy & 0,9 & 0,7 & 0,6 & 0,2 & 2,7 & 1,5 & 1,5 & 0,2 \\
\hline Mołdawia & 3,8 & 1,3 & 6,0 & 0,9 & 7,4 & 0,4 & 9,0 & 0,7 \\
\hline Poland & 9,5 & 11,5 & 18,9 & 20,4 & 80,2 & 94,6 & 92,8 & 98,8 \\
\hline
\end{tabular}

Źródło: opracowanie własne na podstawie danych UN Comtrade.

Obustronne korzyści z wymiany powodowały wzrost produkcji jabłek w Polsce (Kraciński, 2018 b), czego skutkiem po wprowadzeniu embarga były problemy w opłacalnym zagospodarowaniu produkcji (Kraciński, 2015). Mniejszy import jabłek realizowany był w Rosji z Chin, Mołdawii, Białorusi czy Serbii. W wyniku embarga najbardziej wzrosła pozycja konkurencyjna eksportu z Serbii, której udział w wolumenie rosyjskiego importu wzrósł w stosunku do lat 2012-2014 o 17 p.p. do, 24\% w latach 20152016. Jednocześnie przewagi komparatywne serbskiego eksportu na rynku rosyjskim osiagnęeły $\mathrm{w}$ tym czasie najwyższy poziom $(\mathrm{RCA}=12)$, przewyższając mołdawskie $(\mathrm{RCA}=8)$ i białoruskie $(\mathrm{RCA}=7)$. Zgodnie $\mathrm{z}$ danymi UN Comtrade kolejnym (po Serbii) dostawcą na rynek rosyjski w latach 2015-2016 były Chiny, których pozycja konkurencyjna do czasu wprowadzenia embarga systematycznie spadała, tak w odniesieniu do udziału w wolumenie przywozu jak i siły przewag komparatywnych. W stosunku do lat 2012-2014, udział Chin w wolumenie przywozu Rosji, wzrósł o 4 p.p. do 15\% w latach 2015-2016. Eksport z Chin do Rosji miał silne, ale obniżające się przewagi komparatywne w całym badanym okresie, co można powiązać z rosnącymi cenami sprzedaży jabłek z Chin (Nosecka $\mathrm{i}$ in., 2017). Dane UN Comtrade potwierdzają również wzrost pozycji 
konkurencyjnej mierzonej udziałem w eksporcie przywozu do Rosji z Mołdawii (o 3 p.p) oraz Białorusi (1,3 p.p.), przy jednoczesnym obniżeniu się przewag komparatywnych eksportu z tych krajów.

\section{Podsumowanie i wnioski}

Zbiory jabłek rosły niemal we wszystkich (poza Armenią) krajach WNP. Największymi producentami tych owoców w WNP, ze zbiorami przekraczającymi w latach 2015-2016 1 mln ton były Rosja (1,7 mln ton), Ukraina (1,1 mln ton) oraz Uzbekistan (1,1 mln ton). Wśród głównych producentów jabłek w WNP, największa dynamikę wzrostu zbiorów w latach 2014-2015 w stosunku do lat 2006-2008 odnotowano w Uzbekistanie (104\%), na Ukrainie (70\%) i w Mołdawii (60\%). W latach 2005-2016 produkcja jabłek w Mołdawii była $\mathrm{w}$ większości przerabiana na zagęszczony sok jabłkowy i eksportowana. Duży udział zbiorów jabłek eksportowanych w postaci koncentratu jabłkowego obserwowano w tym czasie również na Ukrainie (Kraciński, 2018c). W rosnącej produkcji jabłek krajach WNP może następować wzrost udziału jabłek deserowych. Jednym z czynników wpływających na większe zainteresowanie produkcją jabłek deserowych jest bliskość rynku rosyjskiego, który pozostaje największym światowym odbiorcą takich owoców.

Wśród krajów WNP jedynie Rosja, Białoruś, Kazachstan oraz Ukraina pozostawały we wszystkich latach importerami netto jabłek. Na Ukrainie import netto obniżył się w latach 2015-2016 w stosunku do lat 2006-2008 o 75\%, a w Rosji o 18\%. W tym czasie wzrósł o 294\% import netto na Białorusi oraz o $990 \%$ w Kazachstanie. Zgodnie z oficjalnymi danymi wzrost importu netto w WNP był wyższy niż produkcji jabłek, ale jakość danych nie uprawnia do wyciagnięcia wniosku, że zwiększyło się zapotrzebowanie importowe na jabłka w krajach WNP. Po pierwsze brak było danych handlowych dla 3 krajów WNP, a po drugie w wyniku rosyjskiego embarga doszło do zwiększenie wymiany między Rosją, a Białorusią oraz Rosją i Kazachstanem, która w części mogła nie zostać objęta statystyką. Dla przykładu w 2015 roku, zgodnie z danymi UN Comtrade, Białoruś zaimportowała (głównie z Polski) 731 tys. ton, a wyeksportowała (głownie do Rosji) 611 tys. ton jabłek. W 2016 roku import jabłek na Białoruś wyniósł 599 tys. ton, a eksport z tego kraju zaledwie 113 tys. ton. Tak gwałtowany wzrost zapotrzebowania na jabłka na rynku wewnętrznym Białorusi w 2016 roku wydaje się mało prawdopodobny.

Głównym dostawcą jabłek na Białoruś, z udziałem przekraczającym 50\% w latach 2014-2015 była Polska. Mimo wzrostu wolumenu eksportu z Polski na Białoruś, jego pozycja konkurencyjna mierzona udziałem w wolumenie oraz wskaźnikiem RCA ulegała obniżeniu. Polska stała się $\mathrm{w}$ badanym okresie największym dostawcą jabłek do Kazachstanu z udziałem w latach 2015-2016 wynoszącym 51\% wolumenu importu tego kraju. W Kazachstanie odnotowano wzrost pozycji konkurencyjnej eksportu z Polski mierzony udziałem w rynku oraz silne przewagi komparatywne sprzedaży zagranicznej z tego kraju. Wzrost eksportu do Kazachstanu był zapewne skutkiem rosyjskiego embarga. Polska była największym dostawcą jabłek do Rosji z udziałem w wolumenie importu wynoszącym w latach 2012-2014 47\%. Eksport z Polski miał również silne przewagi komparatywne na rynku rosyjskim. Po wprowadzaniu embarga wzrosła najbardziej na rynku rosyjskim pozycja konkurencyjna dostaw z Serbii, Chin oraz w mniejszym zakresie Mołdawii i Białorusi. Zgodnie z danymi znacznie eksportu z Białorusi było relatywnie 
małe. Wzrost znaczenia Serbii w dostawach do Rosji może mieć związek z realizowaniem reeksportu z innych krajów.

Dane z lat 2006-2016 uwidoczniły, że wzrost produkcji jabłek w krajach WNP był mniejszy niż przyrost importu netto. Należy jednak mieć na uwadze, że dane o imporcie netto mogą być zawyżone, ze względu na realizację przez część krajów WNP reeksportu jabłek. Takie podejrzenia nasuwają m.in. wspomniane dane dla Białorusi za 2016 rok. Dodatkowo okres od inwestycji do uzyskiwania pełni zbiorów w sadownictwie trwa kilka lat, więc impuls do wzrostu produkcji jabłek wywołany rosyjskim embargiem, może przełożyć się na zwiększenie produkcji oraz dopiero w najbliższych latach. Media oraz eksperci rynkowi informowali o inwestycjach przy współudziale dotacji państwowych w sadownictwo w Rosji oraz o niezależnym rozwoju sadownictwa na Ukrainie, Uzbekistanie, Mołdawii i w innych krajach regionu. W dłuższym okresie, nawet w przypadku zniesienia embarga na dostawy do Rosji, możliwy jest spadek pozycji konkurencyjnej jabłek eksportowanych z Polski. Rosnąca produkcja jabłek w krajach WNP może przyczynić się do wzrostu eksportu z tych krajów, czego konsekwencją może być zmniejszenie importu jabłek przez kraje WNP z Polski. W celu redukowania potencjalnych negatywnych skutków utraty rynków WNP należy dążyć do wzrostu produkcji jabłek najwyższej jakości, które będzie można sprzedać na innych rynkach (np. UE). Wymaga to szeregu dostosowań $\mathrm{w}$ zakresie organizacji rynku (m.in. koncentracja podaży poprzez integracje $\mathrm{w}$ silnych organizacjach producenckich oraz wzrostu wiedzy o mechanizmach rynkowych $u$ uczestników rynku.

\section{Literatura}

Balasa, B. (1965). Trade Liberalisation and „Revealed” Comparative Advantage. The Manchester School, 33(2), 99-123.

Bieńkowski, W., Sadza, P. (2000). Rola instytucji w poprawie konkurencyjności gospodarki - zadania dla rządu. W: Konkurencyjność gospodarki polskiej a rola państwa przed akcesją do Unii Europejskiej (The role of institutions in improving the competitiveness of the economy - tasks for the government. In: Competitiveness of the Polish economy and the role of the state before accession to the European Union), Podedworny, J., Grabowiecki, J. (red.), UwB, Białystok.

Budnikowski, A. (2003). Międzynarodowe stosunki gospodarcze (International Economic Relations). PWE Warszawa.

Bugała, A. (2014). Światowy rynek jabłek i zagęszczonego soku jabłkowego (World market of apples and concentrated apple juice). Zeszyty Naukowe SGGW Problemy Rolnictwa Swiatowego, 14(29), 21-30.

Gorynia, M. (2009). Kompendium wiedzy o konkurencyjności (Compendium of knowledge about competitiveness). Gorynia Marian, Łaźniewska Ewa (red.). Wydawnictwo Naukowe PWN, Warszawa.

Filipiak, T. (2016). Handel zagraniczny owocami i przetworami w Polsce w latach 2004-2014 (Foreign trade of fruits and their preserves in Poland in the years 2004-2014). Roczniki Naukowe SERiA, 18(5), 29-35.

Frohberg, K. (2000). Konkurencyjność polskiego rolnictwa. W: Strategiczne opcje dla polskiego sektora agrobiznesu w świetle analiz ekonomicznych (Competitiveness of Polish agriculture. In: Strategic options for the Polish agribusiness sector in the light of economic analysis), Majewski E., Dalton G. (red.), Wydawnictwo Wieś Jutra, Warszawa.

Hinloopen, J., Marrewijk, Ch. (2001). On the empirical distribution of the balassa index. Weltwirtschftliches Archiv.137(1), 1-35.

Jąder, K. (2016). Polski handel zagraniczny owocami i ich przetworami w latach 2001-2015 (Polish foreign trade of fruits and their preserves in Poland in the years 2001-2015). Zeszyty Naukowe SGGW Problemy Rolnictwa Światowego, 16(3), 130-141.

Kowalska, A. (2016). Międzynarodowa konkurencyjność polskiego sektora owocowego po przystapieniu do Unii Europejskiej (International competitiveness of Polish fruit sector following the accession to the European Union). Zeszyty Naukowe SGGW Problemy Rolnictwa Światowego, 16(2), 176-185. 
Kraciński, P. (2018a). Pozycja konkurencyjna Polski na światowym rynku zagęszczonego soku jabłkowego (Competitive position of Poland on the global market of apple concentrated juice). Zeszyty Naukowe $S G G W$ Ekonomika i Organizacja Gospodarki Żywnościowej, 121, 71-81.

Kraciński, P. (2018b). Eksport jabłek z Polski w latach 1995-2015 (Apple export from Poland in the years 19952015). Roczniki Naukowe SERiA, 20(2), 106-111.

Kraciński, P. (2018c). Pozycja Polski na światowym rynku zagęszczonego soku jabłkowego (Polish position on the world market of apple juice concentrate). Roczniki Naukowe SERiA, 20(1), 88-93.

Kraciński, P. (2016). Konkurencyjność największych światowych eksporterów jabłek (The competitiveness of the world's largest exporters of apples). Roczniki Naukowe Ekonomii Rolnictwa i Rozwoju Obszarów Wiejskich, 103(2), 106-118.

Kraciński, P. (2015). Handel zagraniczny jabłkami w UE w kontekście rosyjskiego embargo (The EU foreign trade of apples in the context of the Russian embargo). Zeszyty Naukowe SGGW Problemy Rolnictwa Światowego, 15(3), 83-93.

Kraciński, P. (2014). Eksport produktów ogrodniczych oraz ich przetworów do Rosji i jego udział w rosyjskim imporcie w latach 2001-2012 (Exports of horticultural products and their preserves to Russia and its share in the Russian imports in the period 2001-2012). Zeszyty Naukowe SGGW Problemy Rolnictwa Światowego, 14(2), 107-117.

Nosecka, B., Bugała, A., Kraciński, P., Zaremba, Ł. (2017). Polski i światowy rynek wybranych owoców, warzyw i ich przetworów (Polish and world market of selected fruits, vegetables and their preserves). IERiGŻ-PIB, Warszawa.

Salamaga, M. (2013). Badanie konkurencyjności polskiego eksportu z wykorzystaniem skorygowanego wskaźnika przewagi komparatywnej (Research on export competitiveness in Poland using the adjusted revealed comparative advantage index). Zeszyty Naukowe Uniwersytetu Ekonomicznego w Krakowie, 904, 37-51.

Trajer, M., Smoliński, P., Mieczkowski, M. (2015). Poland's competitiveness in foreign trade in apples. Scientific Journal Warsaw University of Life Sciences, Problems of World Agriculture, 15(4), 178-187.

Woś, A. (2001). Konkurencyjność wewnętrzna rolnictwa (Internal competitiveness of agriculture). IERiGŻ-PIB, Warszawa.

Zawiślińska, I. (2003). Gospodarka Kanady przełomu wieków. Międzynarodowa pozycja konkurencyjna (Canadian economy at the turn of the century. International competitive position). Oficyna Wydawnicza SGH, Warszawa.

UN Comtrade (2018). International Trade Statistics Database. Pobrano 1 czerwca 2018 r. Z: https://comtrade.un.org/.

Do cytowania / For citation:

Kraciński P. (2018). Konkurencyjność polskiego eksportu jabłek na rynki Wspólnoty Niepodległych Państw. Problemy Rolnictwa Światowego, 18(4), 13-22; DOI: 10.22630/PRS.2018.18.4.93

Kraciński P. (2018). The Competitiveness of Apple Exports from Poland to the Markets of Commonwealth Independent States (in Polish). Problems of World Agriculture, 18(4), 13-22; DOI: 10.22630/PRS.2018.18.4.93 